\title{
Bathymetry and Siltation of Oyan Dam, Ogun State, Nigeria
}

\author{
Adejare Q. A. ${ }^{1,}$, Azeez S. A. ${ }^{1}$, Aderibigbe Q. J. ${ }^{2}$ and Adewara M. B. ${ }^{3}$ \\ ${ }^{1}$ Department of Surveying and Geoinformatics, College of Environmental Sciences, Bells University of \\ Technology Ota, Ogun State, Nigeria \\ ${ }^{2}$ Federal School of Surveying Oyo, Nigeria \\ ${ }^{3}$ Department of Surveying and Geoinformatics, College of Environmental Sciences, Federal Polytechnic Ilaro, \\ Ogun State, Nigeria \\ Corresponding Author: *quadriadejare@ yahoo.com
}

https://doi.org/10.36263/nijest.2020.02.0208

\begin{abstract}
Dams are reservoirs established for different reasons. Oyan dam, Ogun State, Nigeria was established and commissioned on the $29^{\text {th }}$ March 1983 to supply water to Lagos State and Abeokuta for municipal uses, with power generation potentials to support Lower Ogun Irrigation Project. However, flooding has become an annual experience of downstream communities along Ogun river especially when the Oyan dam is opened; it has really become remarkable since the flood events of 2012. This project investigates the level of siltation and floods menace adjoining Oyan dam and its environ. An integrated methodology of bathymetric survey, total station traversing and satellite imagery were used to acquire geospatial locations of the dam features and other details within the dam through the process of traversing, heightening and detailing. The field investigation was conducted between January 2018 and January 2020 to determine dam bed topography with the deployment of integrated approach. The collected data were processed using Hydrologic Engineering Center's River Analysis System (HEC-RAS), HYPACK software and ArcGIS 10.6 software. The maximum and minimum depth within the dam is $-4.072 \mathrm{~m}$ and $-21.588 \mathrm{~m}$ respectively. The cross sections are represented for each $200 \mathrm{~m}$ length of the dam. Furthermore, volumetric analysis of sediment budget was computed to be $251.7 \times 10^{6} \mathrm{~m}^{3}$ and compared with designed reservoir capacity of $270 \times 10^{6} \mathrm{~m}^{3}$. From the study, a loss of about $18.2 \times 10^{6} \mathrm{~m}^{3}$ approximately $6.7 \%$ was recorded. Satellite imagery shows the rate of change within Oyan dam and its catchment area downstream based on Triangulated Irregular Network (TIN) generated from Shuttle Radar Topography Mission (SRTM) the maximum and minimum elevation in the catchment are $29 \mathrm{~m}$ and $182 \mathrm{~m}$ respectively. The study recommends the deepening and training of Ogun river and all adjoining drainage systems within the study corridor to retain more water when peak rainfall is recorded.
\end{abstract}

Keywords: Dam, Dredging, Catchment, Floods, Siltation

\subsection{Introduction}

Water is a source of wealth. It is one of the most valuable properties in the life of man and his environment. "WHO (2020) estimated that universal access to safe water and sanitation would result in $\$ 170$ billion of economic benefits each year from reductions in healthcare cost and increased productivity from reduced illness. "Consequently, the demand for freshwater is rising due to several factors, such as population growth, siltation, land use change and climate variations rendering water availability in the future unsustainable (Okello et al., 2015). Ironically, flooding is regarded as the most ubiquitous natural disaster that affects people and urbanization in different dimensions globally. The effects of river floods and storm surges in urban area include: deaths, displacements, acute health impacts and huge economic losses. 'From 1970 to 2008, over 95\% of deaths from natural disasters occurred in developing countries' (IPCC, 2012). UNEP (2016) estimated that adapting to climate changes and coping with damages will cost developing countries $\$ 140-300$ billion per year by 2030 and between $\$ 280-\$ 500$ billion per year in 2050 . 
Furthermore, it was reported that economic losses from flooding in the United States in 2019 were estimated at $\$ 20$ billion (Adam, 2020), annually \$609 million in India, followed by $\$ 19$ million in Bangladesh and \$4 million in Nepal. Similarly, people exposed to river floods annually are 4.84 million people in India, followed by 3.48 million people in Bangladesh (Priya et al., 2017) and approximately 12 million people were displaced in Bangladesh, India and Nepal (ACT Alliance, 2019). Global damage from natural disasters has been steadily increasing, reaching about $\$ 142$ billion annually between 2005-2014; over 1 million died since 2000 and damages cost $\$ 1.7$ trillion (GuhaSapir et al., 2015) and without adaptive measures, disaster damages are expected to rise to $\$ 185$ billion a year from economic and population growth alone (World Bank and United Nations, 2010). Michelle (2016) opined that an average of 22.5 million people annually was displaced by floods, landslides, storms, wildfires and extreme temperatures.

In Nigeria, flood occurrence is connected to heavy rainfall, poor drainage systems, urbanization, deforestation, rural to urban migration, encroachment of flood plain, sand mining and other anthropogenic factors. However, river flooding coupled with urban development intensifies the rate of flooding in the lower section of the Ogun River basin in Southwest Nigeria (Odunuga and Raji, 2014). Oyan dam was established to supply water to Lagos State and Abeokuta for municipal uses and support the 3,000ha Lower Ogun Irrigation Project with power generation potentials. This reservoir is subjected to annual floods from the aforementioned factors since the remarkable floods in 2012. It was reported that in 2012 both River Niger and Benue burst their banks engulfing the small lakes, ponds, farmland highways and settlements within the flood plain with colossal damages to river catchments nationally. Therefore, the development of flood risk plans to deal with these events require estimating the impact of flood along the watercourse in which sediment transportation remains a fundamental component. Sediment disposal into water bodies results in the reduction of water quantity and quality, increasing costs of water purification whilst reducing the available water for various uses (Tundu et al., 2018). According to Olatunji (2012), Oyan river system was explored to determine the main channel suitable sections for discharge measurement and sediment sampling for onsite determination of sediment concentrations. It was reported that an improvement in the stream gauges installations and monitoring can significantly mitigate the impacts of flood in the Oyan dam downstream communities.

Also, the lifespan of a reservoir depends on its sedimentation rate. Reservoirs are prone to siltation faster than anticipated due to failure to protect dam catchment from severe erosion challenges especially in fragile terrains (Awomeso et al., 2009). However, with the construction of the dam coupled with poor reservoir management practices and lack of full utilization of the reservoir water, sediments accumulation within the reservoir remained undisturbed, adjoining drainage channels are too narrow and blocked by debris and trees. Lack of flushing mechanism in the design and construction of the dam leads to an exponential increase in sediment deposit. Unfortunately, Oya dam has failed to serve the purpose it was designed for due to inadequate maintenance, inactive turbines installed and lack of maintenance dredging (Oyegoke and Sojobi, 2012). Furthermore, it was observed from previous studies that the major factor affecting reservoir retaining capacity is the amount of sediment accrued over a period of time which can be determined by hydrographic surveying (Ortt $e t$ al., 2000; Anton et al., 2016; Ruby, 2016). This paper adopted an integration of total station traversing, bathymetric survey and satellite imagery to determine the rate of sediment accrued in a reservoir based on spatial data modelling.

\subsection{Study area}

Oyan dam is located on the confluence of Oyan and Ofiki rivers within geographic coordinates $\left(7^{\circ} 15^{\prime} 16.16^{\prime \prime} \mathrm{N}, 3^{\circ} 15^{\prime} 32.85^{\prime \prime} \mathrm{E}\right.$ and $\left.7^{\circ} 15^{\prime} 40.65^{\prime \prime} \mathrm{N}, 3^{\circ} 15^{\prime} 1.35^{\prime \prime} \mathrm{E}\right)$ at an elevation of $43.3 \mathrm{~m}$ above Mean Sea Level as shown in Figures 1a-c. Rivers Oyan and Ofiki are tributaries of Ogun River approximately twenty (20) kilometres North-West of Abeokuta. Structurally, the dam has an embankment crest length of $1044 \mathrm{~m}, 30.4 \mathrm{~m}$ height, four spillway gates (each $15 \mathrm{~m}$ wide and $7 \mathrm{~m}$ high) and three outlet valves (each $1.8 \mathrm{~m}$ in diameter). The reservoir has a surface area of 4,000ha, catchment area of $9,000 \mathrm{~km}^{2}$, a gross storage capacity of $270 \times 10^{6} \mathrm{~m}^{3}$ and a dead storage capacity of $16 \times 10^{6} \mathrm{~m}^{3}$. It was designed to supply $525 \times 10^{3} \mathrm{~m}^{3}$ and $175 \times 10^{3} \mathrm{~m}^{3}$ of raw water per day to Lagos and Abeokuta (Raphael et al., 2016). Similarly, the dam consists of three inactive turbines of 3.0 Megawatts each installed and commission on $29^{\text {th }}$ March, 1983. 


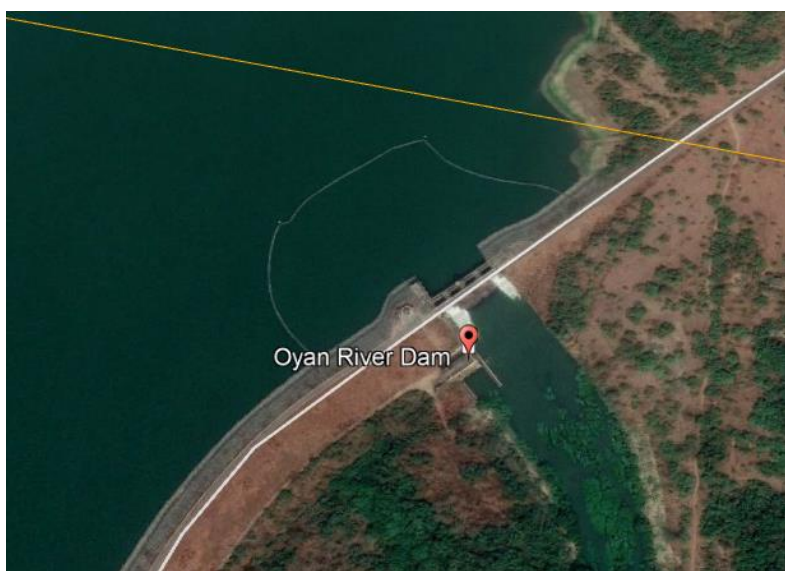

Figure 1a: Satellite imagery of the dam

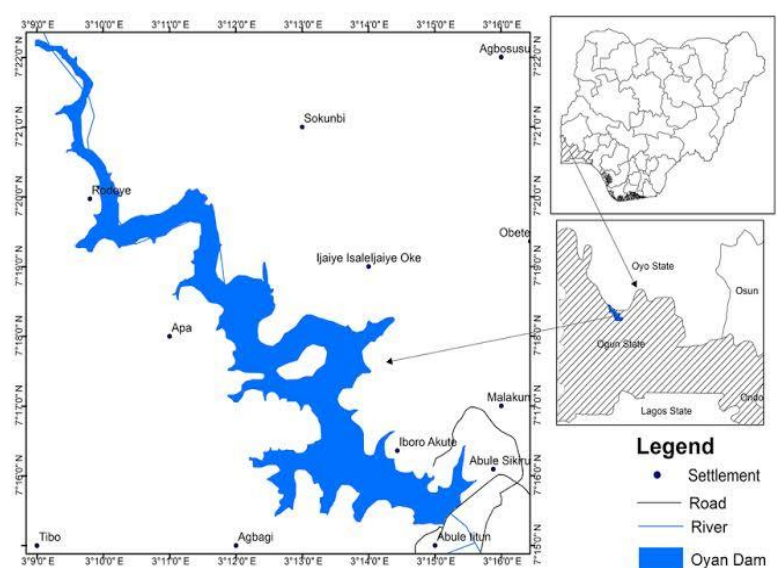

Figure 1b: Map of the study area

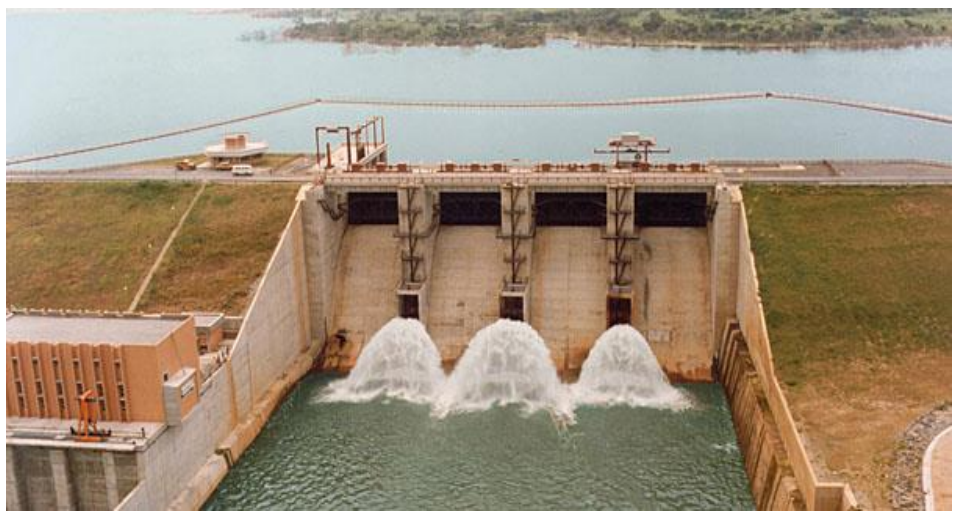

Figure 1c: Spillage section of Oyan dam (Olatunji, 2012)

\subsection{Methodology}

Total station was used for traversing the dam catchment, while Echo sounder was used for bathymetric survey. Remote Sensing was used with the application of satellite imagery dataset to carry out detailed mapping of the dam and its catchment. A total of 2410 points at $50 \mathrm{~m}$ interval were observed using Leica 630E Total Station for perimeter and topographic survey of dam catchment, while South SDE-28S Echo sounder was adopted for depth measurements. The Bathymetric survey was carried out using South SDE- 28S Echo sounder, DGPS receiver and PowerNav Hydrographic Software. The echo sounder was calibrated before and after data acquisition. The transducer was lowered into the Dam then the set up was initialized using the Power NAV software installed on the topside. Power NAV has the capacity of indicating the situation of the vessel on the navigational outline. Thereafter, the software dongle of the Echo Sounder was connected and ensured to be working with the echo sounder calibration. A uniform fixing interval was maintained by regularizing the speed of the survey vessel. The sounding operations covered sounding lines (grid lines) designed parallel to the boundary of the Dam. The abstract of the results are shown in Table 1 . The geometric and depth data in X, Y, Z format were imported into ArcGIS 10.6 for further processing using HECRAS to extract the cross section at 200m., dam depth from Digital Elevation Model (DEM). The cross sections were represented for each $200 \mathrm{~m}$ length of the dam. Similarly, Height of the Dam Crest $\left(\mathbf{C}_{\mathbf{H}}\right)$ and Ground Level $\left(\mathbf{G}_{\mathbf{L}}\right)$ were obtained from the pre-construction drawing obtained from Engineer in charge of the dam while the Height from Dam Crest $\left(\mathbf{C}_{\mathbf{H}}\right)$ to the Water Surface $\left(\mathbf{C}_{\mathbf{W S}}\right)$ was measured on site. Furthermore, sediment budget within dam was generated from the data using ArcGIS 10.6 Triangulated Irregular Network (TIN) as shown in (Figure 2). 
Table 1: Adjusted three dimensional coordinate of discretize points within Oyan dam

\begin{tabular}{|c|c|c|c|c|c|c|c|c|}
\hline \multicolumn{3}{|c|}{ January, 2020} & \multicolumn{3}{|c|}{ January, 2019} & \multicolumn{3}{|l|}{ January, 2018} \\
\hline Easting (m) & Northing $(m)$ & Depth (m) & Easting $(\mathrm{m})$ & Northing $(m)$ & Depth (m) & Easting $(\mathrm{m})$ & Northing $(m)$ & Depth (m) \\
\hline 527647.29 & 802466.57 & 18.33 & 527647.291 & 802466.568 & 18.34 & 527647.288 & 802466.58 & 18.327 \\
\hline 527669.85 & 802421.95 & 17.59 & 527669.851 & 802421.948 & 17.6 & 527669.848 & 802421.96 & 17.587 \\
\hline 527692.41 & 802377.32 & 16.53 & 527692.41 & 802377.32 & 16.5296 & 527692.42 & 802377.3196 & 16.531 \\
\hline 527714.97 & 802332.7 & 15.97 & 527714.97 & 802332.7 & 15.9696 & 527714.98 & 802332.6996 & 15.971 \\
\hline 527737.53 & 802288.08 & 16.16 & 527737.53 & 802288.08 & 16.1596 & 527737.54 & 802288.0796 & 16.161 \\
\hline 527760.09 & 802243.46 & 15.55 & 527760.09 & 802243.46 & 15.5496 & 527760.1 & 802243.4596 & 15.551 \\
\hline 527782.65 & 802198.84 & 14.6 & 527782.65 & 802198.84 & 14.5996 & 527782.66 & 802198.8396 & 14.601 \\
\hline 527556.56 & 802756.86 & 12.16 & 527556.56 & 802756.86 & 12.1596 & 527556.57 & 802756.8596 & 12.161 \\
\hline 527579.12 & 802712.23 & 14.68 & 527579.12 & 802712.23 & 14.6796 & 527579.13 & 802712.2296 & 14.681 \\
\hline 527601.67 & 802667.61 & 18.1 & 527601.671 & 802667.608 & 18.11 & 527601.668 & 802667.62 & 18.097 \\
\hline 524959.56 & 803460.85 & 13.47 & 524959.561 & 803460.848 & 13.48 & 524959.558 & 803460.86 & 13.467 \\
\hline 524936.5 & 803617.27 & 17.89 & 524936.501 & 803617.268 & 17.9 & 524936.498 & 803617.28 & 17.887 \\
\hline 524959.06 & 803572.65 & 16.53 & 524959.061 & 803572.648 & 16.54 & 524959.058 & 803572.66 & 16.527 \\
\hline 524981.62 & 803528.03 & 15.35 & 524981.621 & 803528.028 & 15.36 & 524981.618 & 803528.04 & 15.347 \\
\hline 525004.18 & 803483.41 & 14.17 & 525004.181 & 803483.408 & 14.18 & 525004.178 & 803483.42 & 14.167 \\
\hline 524958.56 & 803684.45 & 14.67 & 524958.561 & 803684.448 & 14.68 & 524958.558 & 803684.46 & 14.667 \\
\hline 524981.12 & 803639.83 & 19.21 & 524981.121 & 803639.828 & 19.22 & 524981.118 & 803639.84 & 19.207 \\
\hline 525003.68 & 803595.21 & 17.57 & 525003.681 & 803595.208 & 17.58 & 525003.678 & 803595.22 & 17.567 \\
\hline 525026.24 & 803550.59 & 16.39 & 525026.241 & 803550.588 & 16.4 & 525026.238 & 803550.6 & 16.387 \\
\hline 527827.27 & 802221.4 & 15.69 & 527827.271 & 802221.398 & 15.7 & 527827.268 & 802221.41 & 15.687 \\
\hline 527646.3 & 802690.17 & 13.88 & 527646.301 & 802690.168 & 13.89 & 527646.298 & 802690.18 & 13.877 \\
\hline 527668.86 & 802645.55 & 16.85 & 527668.861 & 802645.548 & 16.86 & 527668.858 & 802645.56 & 16.847 \\
\hline 527691.41 & 802600.93 & 19.75 & 527691.411 & 802600.928 & 19.76 & 527691.408 & 802600.94 & 19.747 \\
\hline 527713.97 & 802556.31 & 22.42 & 527713.971 & 802556.308 & 22.43 & 527713.968 & 802556.32 & 22.417 \\
\hline
\end{tabular}

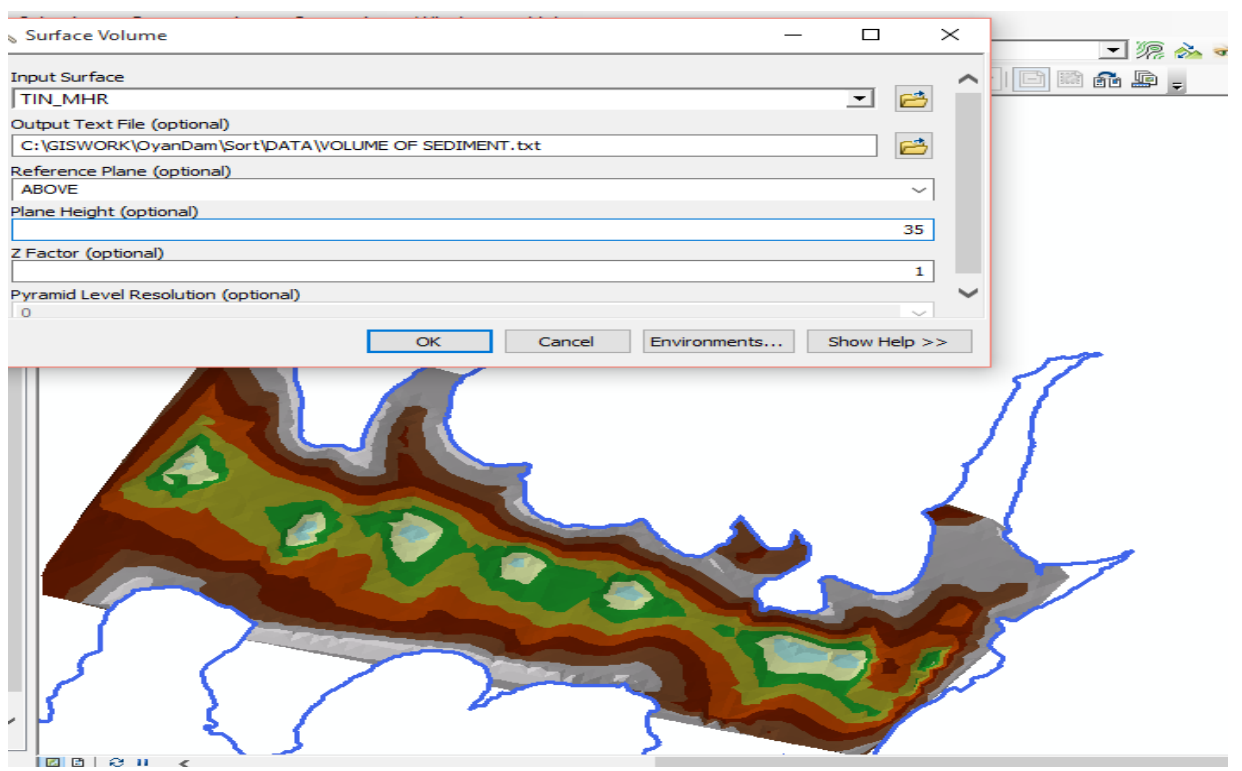

Figure 2: Volume determination process in ArcGIS

\subsection{Computation of sediment volume in the dam}

Sediment Accumulated Volume (SAV) was computed by subtracting the Designed Reservoir Volume (DRV) from the Present Determined Volume (PDV) from field work. This method was previously used by (Adediji, 2005; Adwubi et. al., 2012; Sheikh and Aliyu, 2012; SBADMT, 2002) to compute 
the volume of timeline sediment accumulation in their respective works. Equations (1-4) were used to estimates reservoir volume losses.

$\mathrm{S}_{\mathrm{H}}=\mathrm{S}_{\mathrm{T}}-\mathrm{G}_{\mathrm{L}} \equiv \mathrm{W}_{\mathrm{D}}-\mathrm{G}_{\mathrm{L}}$

$\mathrm{D}_{\mathrm{H}}=\mathrm{C}_{\mathrm{H}}-\mathrm{G}_{\mathrm{L}}$

$\mathrm{W}_{\mathrm{D}}=\mathrm{C}_{\mathrm{H}}-\mathrm{C}_{\mathrm{WS}}+\mathrm{S}_{\mathrm{T}}$

$R_{\text {Anпиа }}=\frac{\left(V_{i}-V_{f}\right)}{t}$

where: $\mathrm{S}_{\mathrm{H}}=$ Sediment Height $(\mathrm{m}) ; \mathrm{S}_{\mathrm{T}}=$ Sediment Top $(\mathrm{m}) ; \mathrm{G}_{\mathrm{L}}=$ Ground Level $(\mathrm{m}) ; \mathrm{W}_{\mathrm{D}}=$ Water Depth $(\mathrm{m}) ; \mathrm{D}_{\mathrm{H}}=$ Dam Height $(\mathrm{m}) ; \mathrm{C}_{\mathrm{H}}=$ Crest Height $(\mathrm{m}) ; \mathrm{C}_{\mathrm{WS}}=$ Crest to Water Surface $(\mathrm{m}) ; \mathrm{R}_{\text {Annual }}$ is the mean annual actual sedimentation volume in $\left(\mathrm{Mm}^{3} /\right.$ year); $\mathrm{V}_{\mathrm{i}}$ is the initial reservoir volume in $\left(\mathrm{Mm}^{3}\right)$; $V_{\mathrm{f}}$ is the final reservoir volume in $\left(\mathrm{Mm}^{3}\right)$; $\mathrm{t}$ is the number of years (year) under consideration.

From field observation and schematic diagram of the reservoir sedimentation in this study, the

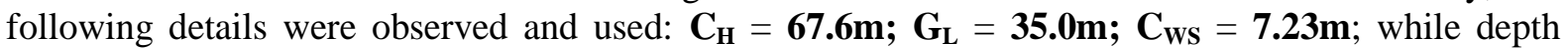
measurements were used to generate TIN as shown in Figure 2.

\subsection{Results and Discussion}

The volume of sediment within the dam was calculated using ArcGIS 10.6 TIN and cross sections are represented in (Figures 3a-3t) respectively. Table 1 shows the adjusted coordinate of discretize points, this was used to further generate Table 2, while the former shows $\mathrm{X}, \mathrm{Y}, \mathrm{Z}$ position with respect to bathymetric at each section, the later presented the mean of sediment yield within the Dam. The river channel is divided into sections of $200 \mathrm{~m}$ each. The cross sections are represented for each $200 \mathrm{~m}$ length and $80 \mathrm{~m}$ width of the dam as shown in Figures 3a- 3t and Table2.

Table 2: Sorted and reduced $\mathrm{X}, \mathrm{Y}, \mathrm{Z}$ data for computation of sediment yield in the dam

\begin{tabular}{|l|l|l|l|l|l|l|l|}
\hline Easting & Northing & Height & $\begin{array}{l}\text { Crest } \\
\text { Height }\end{array}$ & $\begin{array}{l}\text { Crest To Water } \\
\text { Surface (CWS) }\end{array}$ & $\begin{array}{l}\text { Original } \\
\text { Ground Level }\end{array}$ & $\begin{array}{l}\text { Height of Re } \\
\text { Bed }\end{array}$ & Sediment \\
\hline 524869.820 & 803527.530 & 10.61 & 67.60 & 7.23 & 35.00 & 49.76 & 14.76 \\
\hline 524892.380 & 803482.910 & 16.16 & 67.60 & 7.23 & 35.00 & 44.21 & 9.21 \\
\hline 524914.940 & 803438.290 & 17.35 & 67.60 & 7.23 & 35.00 & 43.02 & 8.02 \\
\hline 524937.500 & 803393.670 & 14.40 & 67.60 & 7.23 & 35.00 & 45.97 & 10.97 \\
\hline 524914.440 & 803550.090 & 17.42 & 67.60 & 7.23 & 35.00 & 42.95 & 7.95 \\
\hline 524937.000 & 803505.470 & 15.89 & 67.60 & 7.23 & 35.00 & 44.48 & 9.48 \\
\hline 524959.560 & 803460.850 & 13.47 & 67.60 & 7.23 & 35.00 & 46.90 & 11.90 \\
\hline 524936.500 & 803617.270 & 17.89 & 67.60 & 7.23 & 35.00 & 42.48 & 7.48 \\
\hline 524959.060 & 803572.650 & 16.53 & 67.60 & 7.23 & 35.00 & 43.84 & 8.84 \\
\hline 524981.620 & 803528.030 & 15.35 & 67.60 & 7.23 & 35.00 & 45.02 & 10.02 \\
\hline 525004.180 & 803483.410 & 14.17 & 67.60 & 7.23 & 35.00 & 46.20 & 11.20 \\
\hline 524958.560 & 803684.450 & 14.67 & 67.60 & 7.23 & 35.00 & 45.70 & 10.70 \\
\hline 524981.120 & 803639.830 & 19.21 & 67.60 & 7.23 & 35.00 & 41.16 & 6.16 \\
\hline 525003.680 & 803595.210 & 17.57 & 67.60 & 7.23 & 35.00 & 42.80 & 7.80 \\
\hline 525026.240 & 803550.590 & 16.39 & 67.60 & 7.23 & 35.00 & 43.98 & 8.98 \\
\hline 525048.800 & 803505.970 & 15.22 & 67.60 & 7.23 & 35.00 & 45.15 & 10.15 \\
\hline 525003.190 & 803707.010 & 16.31 & 67.60 & 7.23 & 35.00 & 44.06 & 9.06 \\
\hline 525025.740 & 803662.390 & 19.21 & 67.60 & 7.23 & 35.00 & 41.16 & 6.16 \\
\hline
\end{tabular}

While, Figure $3 u$ is the TIN generated from SRTM data of the subject site with details of drainage system and other land forms; Figures 3a- 3t shows longitudinal and vertical profiles that revealed depth changes within Oyan dam which was used to compute sediment accrued. The study reveals a 
sediment budget of $18.2 \times 10^{6} \mathrm{~m}^{3}$ based on bathymetric chart presented in Figure $3 \mathrm{a}$. It is important to note that maximum rain is recorded between June, July and September each year with a recommended dam discharge height of $56 \mathrm{~m}-62 \mathrm{~m}$ against Dam $\mathbf{C}_{\mathbf{H}}$ of $67.6 \mathrm{~m}$. An increase in water level above $62 \mathrm{~m}$ in the dam poses a threat to catchment areas within the study corridors. The catchment areas are fragile wetland with unstructured sand mining activities and encroachment of flood plain as a result of rural urban migration. The resultant effect is floods that bring economic losses, destruction of farm land and man hour loss. It is instructive to note that Lagos State Government has urged residents of affected areas to relocate in June 2020. This advice was in response to proposed schedule of water volume to be released in 2020 from Oyan dam as follows: $5 \times 10^{6} \mathrm{~m}^{3}$ in June; $10 \times 10^{6} \mathrm{~m}^{3}$ in July; $8 \times 10^{6} \mathrm{~m}^{3}$ in September; $23 \times 10^{6} \mathrm{~m}^{3}$ in October respectively.

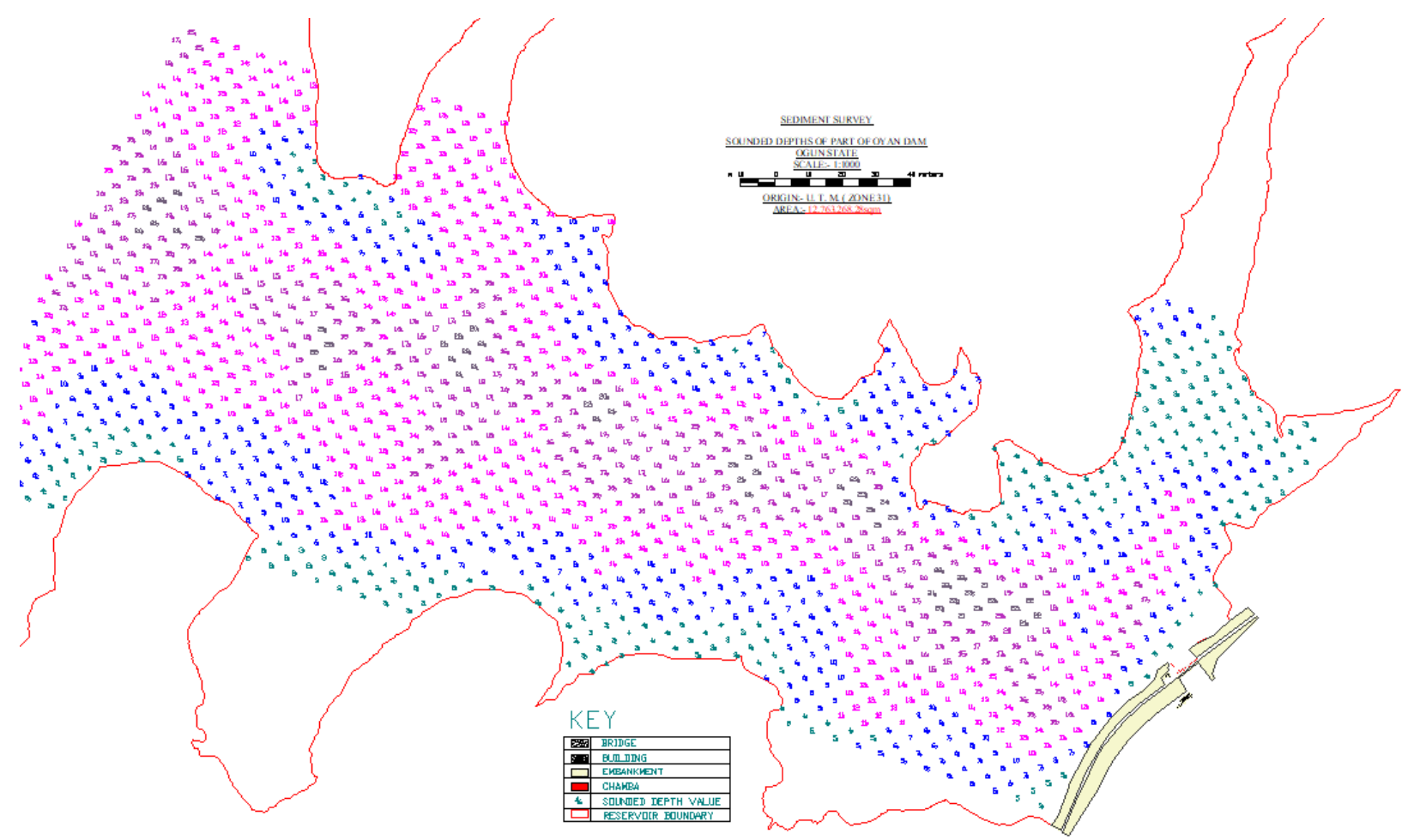

Figure 3a: Bathymetric chart of Oyan dam
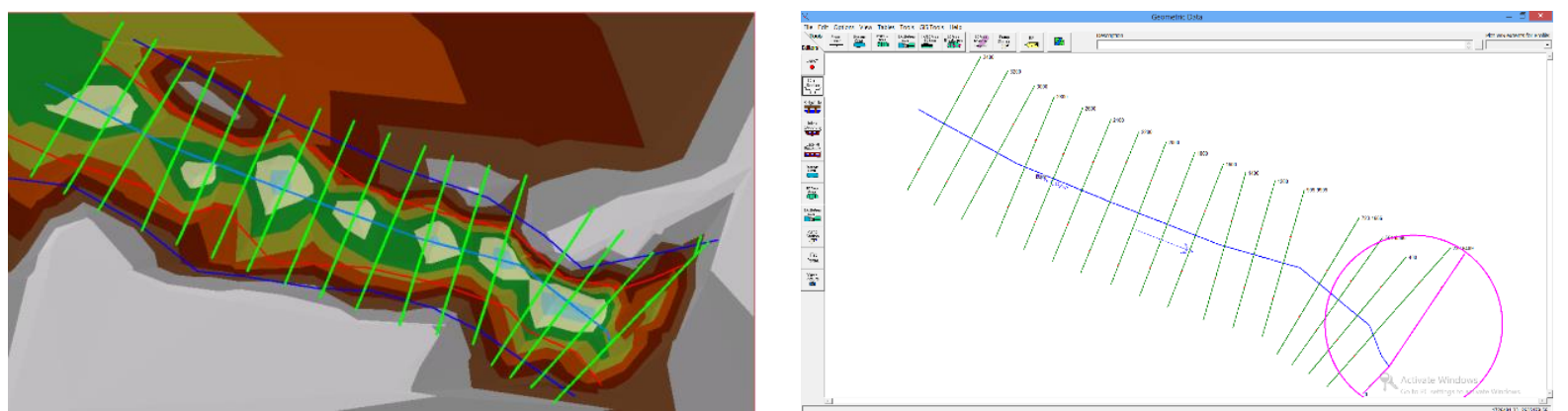

Figure 3b: Cross sectional line at 200m interval and the width is $80 \mathrm{~m}$ across the centre line
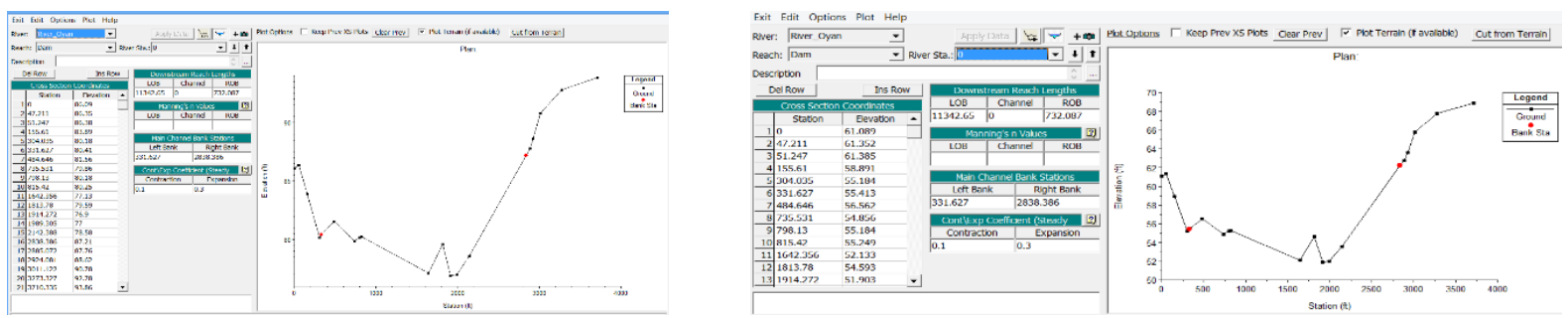

Figure 3c: Longitudinal section along the centre line 


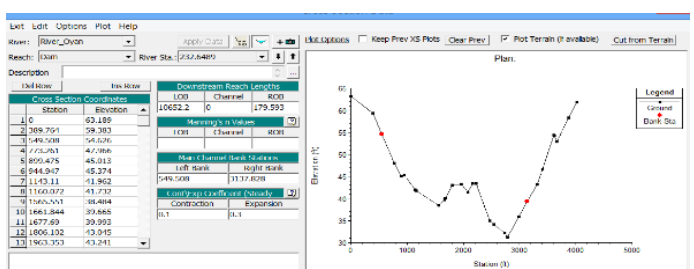

Figure 3d: Cross section @ 0.00m

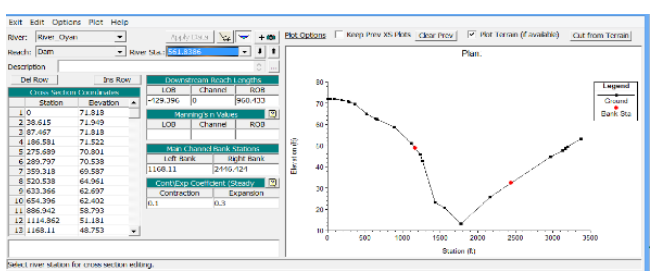

Figure 3f: Cross section @ 400.00

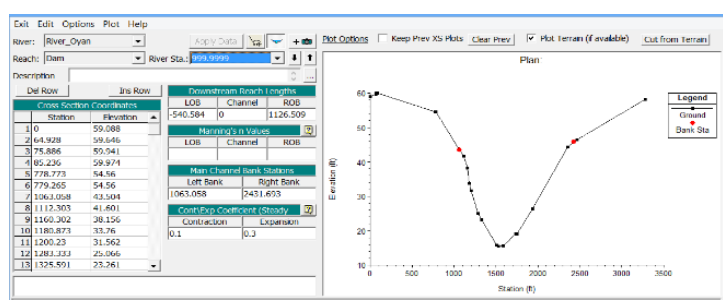

Figure 3h: Cross section@ $923.17 \mathrm{~m}$

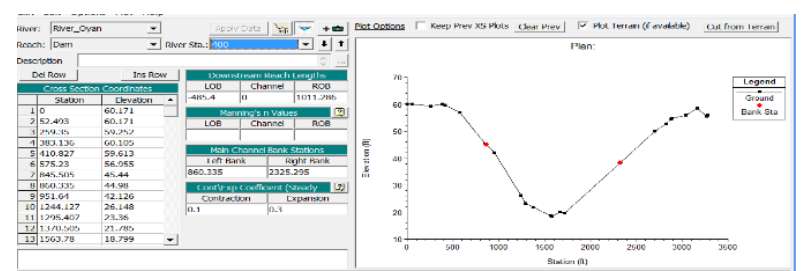

Figure 3e: Cross section @ 232.65m

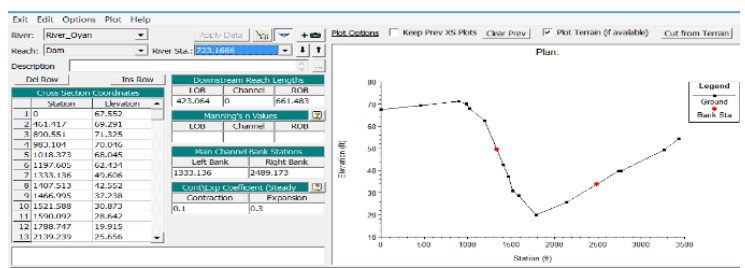

Figure 3g: Cross section@ @ 561.84m

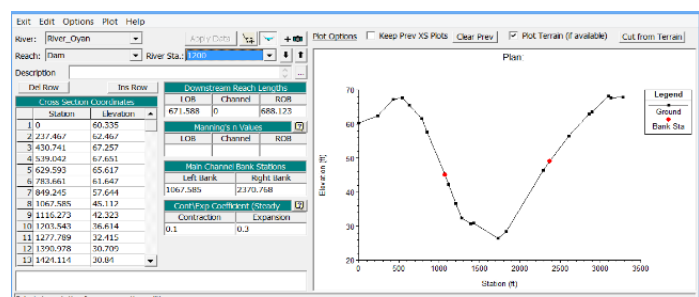

Figure 3i: Cross section @ 1000.00m

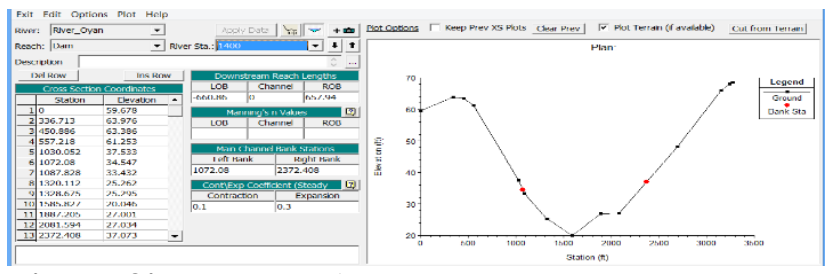

Figure 3j: Cross section@ 1400.00m

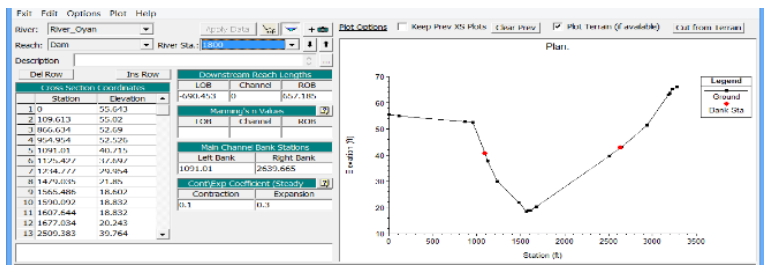

Figure 31: Cross section @ 1800.00m

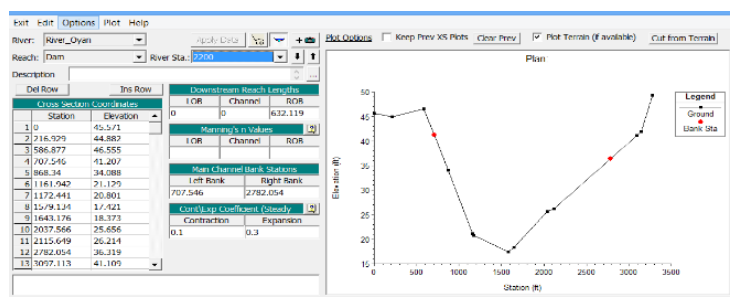

Figure 3n: Cross section@ 2200.00m

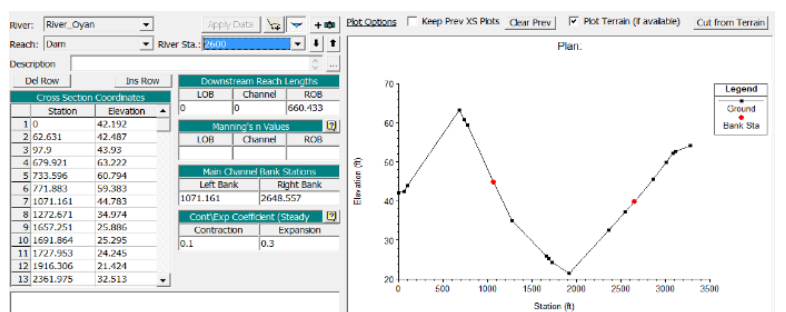

Figure 3p: Cross section@ 2600.00m

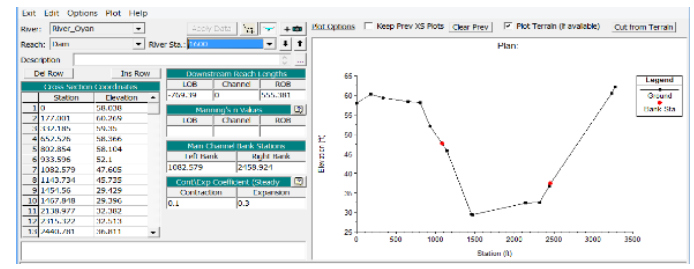

Figure 3k: Cross section@ 1600.00m

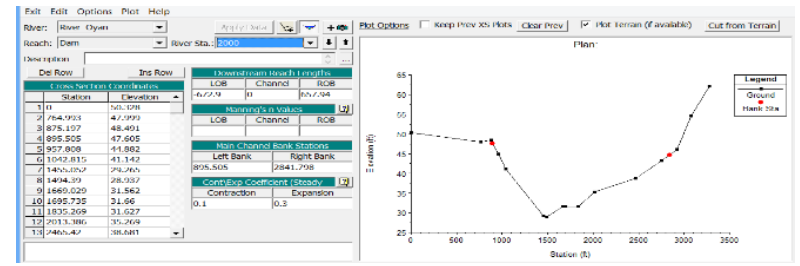

Figure 3m: Cross section @ 2000.00m

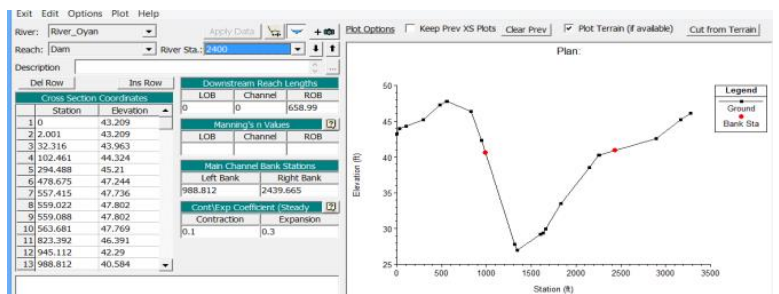

Figure 3o: Cross section@ 2400.00m

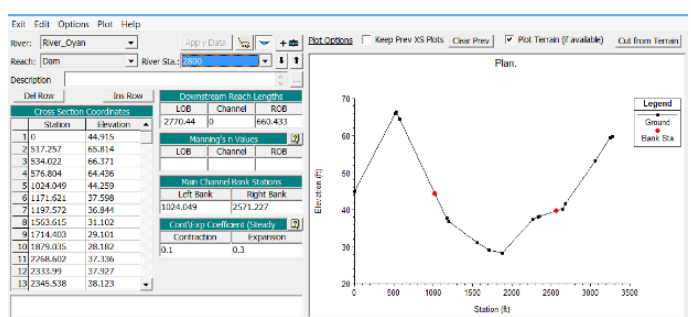

Figure 3q: Cross section@ 2800.00m 


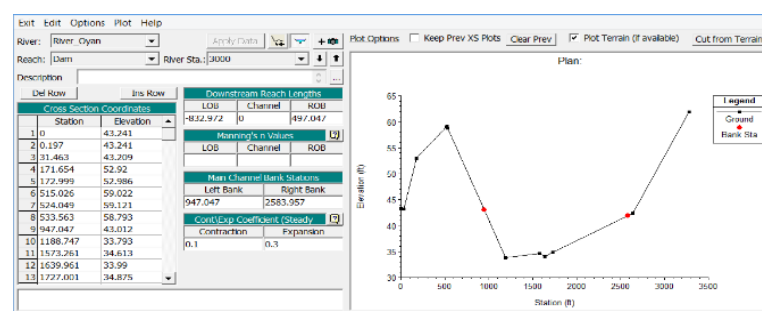

Figure 3r: Cross section@ 3000.00m

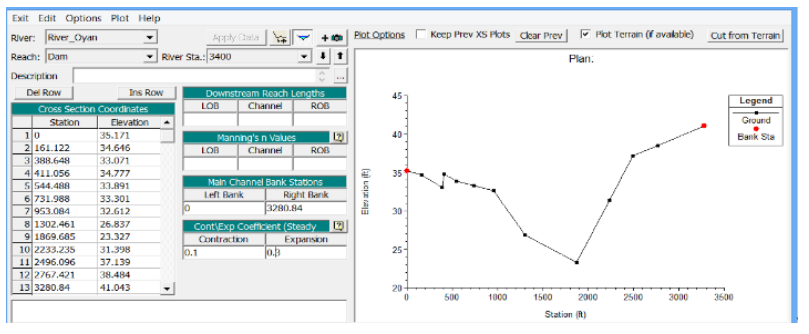

Figure 3t: Cross section @ 3400.00m

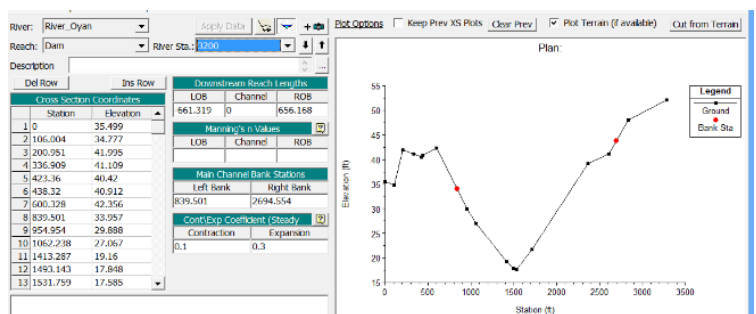

Figure 3s: Cross section@ 3200.00m

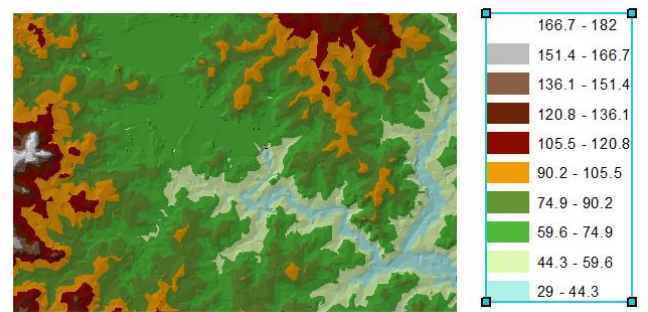

Figure 3u: TIN generated from the SRTM data

Moreover, it was observed that the maximum and minimum elevation of the area ranges from -4.072 to $-21.588 \mathrm{~m}$. The study revealed that there are sediments in the reservoir between January 2018 and January 2020 as compared to pre-construction period of the dam. From the design parameters the reservoir was configured to hold $270 \times 10^{6} \mathrm{~m}^{3}$ of water. Silting sediment covering a volume of $18.3 \times 10^{6} \mathrm{~m}^{3}$ has reduced the water holding capacity of the reservoir to $251.7 \times 10^{6} \mathrm{~m}^{3}$, approximately $6.78 \%$ drop in capacity as detailed in Figure 3 a. Sediment accrued in the dam is approximately $26^{\text {th }}$ times daily water production of $700 \times 10^{3} \mathrm{~m}^{3}$ to Lagos and Abeokuta as stipulated in the design. Therefore, the reservoir water quality will be affected by these sediments and floods, because water level fluctuation has long been recognized as an effective control method against diseases. From the profiles, centre line of the river has the highest value while areas close to the shore has the lowest value. While constructing TIN, elevation range was reclassified into nine classes as shown in the Figure 3t. Similarly, the TIN generated from the DEM download after being classified into 9 classes shows that the highest and the lowest points are $29 \mathrm{~m}$ and $182 \mathrm{~m}$ respectively. Sediment budget within Oya dam would reduce water holding capacity and lead to flooding of the communities at the downstream, thus exposing residents to impending cholera, diarrhea, malaria, skin infections and other water-borne diseases epidemic (Etuonovbe, 2011).

\subsection{Conclusions}

This study demonstrates the ability of bathymetric survey, total station traversing and GIS techniques in capturing spatial data, monitoring, maintenance and management of the reservoir. The results revealed a loss in water volume totalling about $18 \times 10^{6} \mathrm{~m}^{3}$, from the study when compared with original designed capacity due to sediment trapped. This will lead to reduction in reliability of water supply, increase cost of water purification, aggravated flooding within the catchment and destruction of boulders during excessive rainfall. As an adaptation strategy to climate change, an increase in water volume experience due to excessive rainfall should be channelled to power the hydropower turbines. It is therefore recommended that a mini-hydropower can be generated from the dam if the sediment budget is monitored at regular intervals. This would serve as a cheaper energy source for lifting water away from the dam area to adjacent lands. The study recommends deepening and training of Ogun River and all adjoining drainages system within the study corridor to retain more water. Areas for further study include sediments analysis in the laboratory to determine their physico-chemical characteristics in order to ascertain their impact on the consumption of the reservoir water.

\section{References}

ACT Alliance (2019). ACT Alliance Regional Alert: South Asia Floods 23th July 2019. Available at https://reliefweb.int (accessed on 19 ${ }^{\text {th }}$ June 2020).

Adam, B. S. (2020). 2010-2019: A landmark decade of U.S. billion-dollar weather and climate disaster. Available at https:www.climate.gov (accessed $3^{\text {rd }}$ June 2020). 
Adediji, A. (2005). Reservoir Sedimentation: The case of Opa Reservoir catchment, Southwestern Nigeria. South African Geographical Journal, 87(2), pp. 123 - 128.

Adwubi, A., Amegashie, B. K., Agyare, W. A., Tamene, L., Odai, S.N., et al., (2012). Assessing sediment inputs to small reservoirs in Upper East Region, Ghana Lakes and Reservoirs. Research and Management, 14(4), pp. 279 -287.

Anton, J. S., Mário, J. F., Carmelo, J. and Giovanni, C. (2016). Reservoir sedimentation. Journal of Hydraulic Research, 54(6), pp. 595-614.

Awomeso, J. A., Ufoegbune, G. C., Gbadebo, A. M., Balogun, G. O. and Eruola, A. O. (2009). Towards Effective Planning, Design and Monitoring of Dams in Nigeria. Journal of Agricultural Science and Environment, 9(2), pp. 45-63.

Etuonovbe, A. K. (2011). Devastating Effect of Flooding in Nigeria. FIG Working Week 2011. Bridging the Gap between Cultures Marrakech, Morocco, 18-22 May 2011

Guha-Sapir, D., Below R. and Hoyois, Ph. (2015). EM-DATi: International Disasters Database. Universite Catholique de Louvain - Brussels Belgium.

IPCC (2012). Managing the Risks of Extreme Events and Disasters to Advance Climate Change Adaptation. Special Report. Cambridge, UK and New York, USA: Cambridgeniversity Press.

Odunuga, S. and Raji, S. A. (2014). Flood Frequency Analysis and Inundation Mapping of Lower Ogun River Basin. Journal of Water Resource and Hydraulic Engineering, 3(3), pp. 48-59.

Olatunji, T. (2012). Towards effective Hydrological Measurements downstream of Oyan dam. Hydrology for Disaster Management: Special Publication of the Nigerian Association of Hydrological Sciences, pp. 121-131.

Okello, C., Tomasello, B., Greggio, N., Wambiji, N., and Antonellini, M. (2015). Impact of Population Growth and Climate Change on the Freshwater Resources of Lamu Island, Kenya. Journal Water, 1.

Ortt, A. R., Kerhin, T. R., Wells, D. and Cornwell, J. (2000). Bathymetric Survey and Sedimentation Analysis of Loch Raven and Pretty Boy Reservoirs. Department of Natural Resources: Coastal and Estuarine Geology file Report No. 99-4: Maryland Geological Survey, Baltimore

Oyegoke, S. O. and Sojobi, A. O. (2012). Developing Appropriate Techniques to Alleviate the Ogun River Network Annual Flooding Problems. International Journal of Scientific \& Engineering Research, 3(2), pp. 1-7.

Michelle, Y. (2016). Disaster-related displacement in a changing climate. Internal Displacement Monitoring Centre (IDMC). Bulletin: 65 (1). Accessed $10^{\text {th }}$ June 2020. https://public.wmo.int/en/resources/bulletin/disaster-related-displacement-changing-climate

Priya, S., Young, W., Hopson, T. and Avasthi, A. (2017). Flood Risk Assessment and Forecasting for the Ganges-Brahmaputra-Meghna River Basins. Water Global Practice, World Bank Group. pdfdocuments.worldbank.org

Raphael, O. D., Adekanye, T. A. and Alhassan, A. E. (2016). Maximizing the Full Economic Potentials of Ikere Gorge and Oyan Dams for National Economic Development. African Journal of Agricultural Science and Technology (AJAST), 4(3), pp. 633-641.

Ruby, A. T. (2016). Methods for noninvasive bathymetric and velocity surveys for impoundment safety-A case study of Herrington Lake at Dix Dam near Burgin, Kentucky. Kentucky: U.S. Geological Survey Scientific Investigations Map 3198, https://pubs.usgs.gov/sim/3198/. 
Sheikh, D. A. and Aliyu M. (2017). Examining Sediment Accumulation in Goronyo Reservoir, Sokoto State, Nigeria. IOSR Journal of Humanities and Social Science IOSR-JHSS, 22(8), pp. 60-65.

SBADMT, (2002). Single Beam Acoustic Depth Measurement Techniques. Available at [http://www.syqwesti nc.com/media/support/depthmeasuringtechniques.pdf] (accessed $10^{\text {th }}$ January 2020).

Tundu, C., Tumbare, M. J. and Onema, J. K. (2018). Sedimentation and Its Impacts/Effects on River System and Reservoir Water Quality: Case Study of Mazowe Catchment, Zimbabwe. Proc. International Association of Hydrological Sciences, 377: 57.

UNEP's Adaptation Finance Gap Report, (2016) Available at www.oxfam.org/natural-disasters-begclimate-action (accessed $1^{\text {st }}$ June 2020).

WHO (2020): Water and Climate Change: The United Nations World Water Development Report 2020: www.unesco.org/water/wwap.

World Bank and United Nations. (2010). Natural Hazards, UnNatural disasters: The Economics of Effective Prevention. Washington, DC: IBRD/The World Bank.

Cite this article as:

Adejare Q. A., Azeez S. A., Aderibigbe Q. J. and Adewara M. B., 2020. Bathymetry and Siltation of Oyan Dam, Ogun State, Nigeria. Nigerian Journal of Environmental Sciences and Technology, 4(2), pp. 314-323. https://doi.org/10.36263/nijest.2020.02.0208 